\title{
Evaluation of Anti-Diabetic and Anti-Hyperlipidemic Activities of Hydro-Alcoholic Crude Extract of the Shoot Tips of Crinum abyssinicum Hochst. ex A. Rich (Amaryllidaceae) in Mice
}

\author{
Bantayehu Addis Tegegne (D)', Abebe Basazn Mekuria $\mathbb{D}^{2}$, Eshetie Melese Birru $\mathbb{D}^{2}$ \\ 'Department of Pharmacy, College of Health Sciences, Debre Markos University, Debre Markos, Ethiopia; ${ }^{2}$ School of Pharmacy, College of Medicine \\ and Health Science, University of Gondar, Gondar, Ethiopia \\ Correspondence: Bantayehu Addis Tegegne, Department of Pharmacy, College of Health Sciences, Debre Markos University, Debre Markos, \\ Ethiopia, Tel +25I9 13326285 , Email bantayehuaddis.90@gmail.com
}

Background: Despite the availability of synthetic antihyperglycaemic medications on the market, diabetes is on the rise. Though not scientifically proven, the Crinum abyssinicum Hochst. ex A. Rich. (Amaryllidaceae) has been used traditionally to treat diabetes. Crinum abyssinicum was tested in mice to see if it had anti-diabetic and anti-hyperlipidemic properties.

Methods: The hydro-alcoholic extract of Crinum abyssinicum shoot tips doses (100 mg/kg, $200 \mathrm{mg} / \mathrm{kg}$, and $400 \mathrm{mg} / \mathrm{kg}) \mathrm{were}$ administered to normoglycemic, oral glucose-loaded mice, and single and repeated dose-treated streptozotocin-induced diabetic model. Then, the blood glucose levels were measured for normoglycemic, oral glucose loaded and single dose treated streptozotocin model. Whereas in repeated dose-treated streptozotocin induced diabetic model, blood glucose level, body weight, and lipid profiles were measured.

Results: After oral administration, all extract doses $(100 \mathrm{mg} / \mathrm{kg}(\mathrm{p}<0.01), 200 \mathrm{mg} / \mathrm{kg}(\mathrm{p}<0.001)$, and $400 \mathrm{mg} / \mathrm{kg}(\mathrm{p}<0.001))$ significantly reduced blood glucose level of normal mice as compared to the control group. Significant reduction of post-prandial glucose was achieved with crude extract at a tested dose of $100 \mathrm{mg} / \mathrm{kg}(\mathrm{p}<0.05)$ both at 1 st and $2 \mathrm{nd} \mathrm{hours;} 200 \mathrm{mg} / \mathrm{kg}(\mathrm{p}<0.01)$ at the 1 st hour and $(\mathrm{p}<0.001)$ 2nd hours, and $400 \mathrm{mg} / \mathrm{kg}(\mathrm{p}<0.001)$ at the $1 \mathrm{st}$ and 2 nd hours as compared to the negative control. In diabetic mice, the crude extract $200 \mathrm{mg} / \mathrm{kg}$ and $400 \mathrm{mg} / \mathrm{kg}$; and glibenclamide $5 \mathrm{mg} / \mathrm{kg}$ significantly reduced $(\mathrm{p}<0.001)$ blood glucose level on the 14th day as compared to the negative control. All doses of crude extract significantly improved the lipid profiles and the bodyweight of diabetic mice.

Conclusion: These findings revealed that the hydro-alcoholic extract of Crinum abyssinicum shoot tips possess significant antihyperglycemic, antihyperlipidemic, and body weight improvements in streptozotocin-induced diabetic mice. Besides, it showed hypoglycaemic and anti-hyperglycaemic activities on normoglycemic and oral glucose loaded mice, respectively. These justify the claimed use of the plant in ameliorating diabetes mellitus in Ethiopian folk medicine.

Keywords: antidiabetic, antihyperlipidemic, Crinum abyssinicum, hydro-alcoholic, streptozotocin

\section{Background}

Diabetes Mellitus (DM) is a metabolic condition that is chronic and non-communicable. ${ }^{1}$ It is a growing global health problem that is viewed as an "iceberg" hormonal disease defined by a loss of control over blood glucose levels as a result of carbohydrate, lipid, and protein metabolic dysfunctions. In about one-third to one-half of patients with diabetes, microvascular (retinopathy, nephropathy, and neuropathy) and macro-vascular (ischemic heart disease, peripheral vascular disease, and cerebrovascular disease) problems are tightly linked. ${ }^{2}$ Uncontrolled hyperglycemia can cause consequences such as increased lipid peroxidation, superoxide generation, lipoprotein glycation, and oxidative DNA damage through tissue protein glycation. Reactive species such as hydrogen peroxides $\left(\mathrm{H}_{2} \mathrm{O}_{2}\right)$ and hydroxyl radicals are produced as 
a result of glycation and glucose auto-oxidation ( $\mathrm{OH}-)$. As a result, it has a global impact on human life in one or more ways. $^{3-5}$

$\mathrm{DM}$ is common worldwide, and its incidence is on the rise, with disproportionately higher rates in low- and middleincome countries (LMICs), and its fatality rate is steadily rising. According to a World Health Organization (WHO) report from 2019, a little under half a billion people worldwide have diabetes, with the number expected to rise by $25 \%$ in 2030 and 51\% in 2045. ${ }^{6,7}$ Diabetes has become a major health issue in Ethiopia, as it has throughout the world. With a prevalence of diabetes, pre-diabetes, and previously undiagnosed diabetes of $6.8 \%, 15.7 \%$, and $72.5 \%$, respectively. Ethiopia is among the top four nations in sub-Saharan Africa with the largest number of persons with diabetes and hospital admissions owing to diabetes. ${ }^{7,8}$

Despite the introduction of various types of traditional oral hypoglycaemic medications on the market, diabetic prevalence and health-care spending are rising at an alarming rate around the world. Diabetes is expected to cost the world economy USD 760 billion, USD 825 billion, and USD 845 billion in 2019, 2030, and 2045, respectively. ${ }^{9}$ As a result, these issues necessitate the development of new anti-diabetic drugs derived from natural sources, particularly plants, that are safe, readily available, more efficacious, have a novel mode of action, broad therapeutic potential, and are structurally distinct from currently available drugs. ${ }^{10,11}$

Herbal medicines are encouraged, recommended, and promoted by WHO in national health care programs because they are inexpensive, reasonably safe, and have a high level of trust among the people.

Because of their bioactive phytochemical contents (nitrogen-containing alkaloids, phenols, flavonoids, saponins, tannins, and other compounds), medicinal plants offer antioxidation, anti-inflammatory, and anti-diabetic properties. ${ }^{2,12-14}$ These phytochemical ingredients have anti-hyperglycaemic properties through restoring pancreatic tissue function, resulting in an increase in insulin secretion, or by inhibiting glucose absorption in the intestine or facilitating metabolite transport in insulin-dependent processes. ${ }^{15,16}$ Furthermore, natural antioxidants may help with diabetes management by offering protection against free radical damage. Natural products, on the other hand, have received a lot of attention as sources of bioactive substances like antioxidants, hypoglycaemic, and anti-hyperlipidaemia by lowering plasma insulin and Glycated haemoglobin (HbAlc) levels. Maintaining a lipid profile is vital to lower the risk of coronary heart disease and atherosclerosis caused by diabetes, as it may occur from diabetic dyslipidaemia (hyperlipidaemia). In comparison to non-diabetics (normal mice), raised serum Triglycerides (TGs), Very Low-Density Lipoprotein (VLDL), high small dense Low-Density Lipoproteins (LDL), and low serum High-Density LipoproteinCholesterols (HDL-C) levels are connected with the most prevalent problem in diabetes patients. ${ }^{2,5}$

Enzyme inhibitory theory is regarded as one of the most effective therapeutic approaches for addressing global health issues such as DM. As a result, lipolysis blockade has emerged as a unique method for the treatment of obesity and its comorbidities. Many plants contain arginine-containing tri-peptides (Pro-Arg-Gly), which are thought to be effective phospholipase inhibitors and involved in the regulation of anticoagulation and insular systems function under persistent hyperglycemia. ${ }^{17,18}$ In diabetic rats, the nutraceutical potential of Corylus avellana daily supplement for obesity and dysmetabolism $^{19}$ and Juglans regia L. leaf powder was investigated, and effective glycaemic control and dyslipidemias reversal were seen. ${ }^{20}$

The Amaryllidaceae family, which includes 79 genera, is a highly ubiquitous monocotyledonous family found in all biomes around the world. ${ }^{21}$ Crinum is one of the therapeutic plants in this family, which includes several species with bulbous geophytes and grows in places with a lot of seasonality. ${ }^{22}$ Lycorine, epihalmanthidine, crinafolidine, crinasiatine, precriwelline, crimine, narciclasine, crinamine, crinamide, lycobetaine, criasbetaine, crinasiadine, and crotepoxide are among the phytochemical chemicals found in it. Plant extracts rich in lycorine and other alkaloids have anti-oxidant, antiinflammatory, cytotoxic, immune-stimulating, analgesic, antiviral, antimalarial, antimicrobial, and anti-diabetic properties, as well as anti-diabetic properties. ${ }^{23,24}$ Different solvent extracts have been generated from the leaves and bulbs of crinum species in numerous biological experiments due to their significant phytochemical ingredients with vast pharmacological activity. ${ }^{25}$ Plants in this family, such as Allium sativum (garlic) and Allium cepa (onion), have shown strong antioxidant and hypoglycaemic activities in pharmacological studies. ${ }^{21}$ Furthermore, ethanol and aqueous extracts of Crinum latifolium linn's leaves demonstrated considerable anti-diabetic potential. ${ }^{26}$ Crinum jagus aqueous and hydro-alcoholic extracts have anti-oxidant and anti-diabetic effects in vitro and in vivo, respectively. ${ }^{27}$ This suggests that, 
like the aforementioned plants, the study plant may have anti-oxidant and anti-diabetic properties. The existence of considerable bioactive elements (alkaloids, flavonoids, saponins, tannins, and phenols) was confirmed in a prior qualitative and quantitative phytochemical examination on the bulbs of Crinum abyssinicum ${ }^{28}$ that is already recognized to have anti-oxidant and blood glucose reducing properties. In Ethiopia, an ethno-medicinal survey and qualitative exploratory research revealed that the herb is consumed orally for the treatment of diabetes mellitus. ${ }^{23,29-31}$

Crinum abyssinicum Hochst. ex A. Rich. is locally known as "yejib shinkurt" in Amharic ${ }^{32}$ and "Murquffaa"/ Shinkurta/boko lo werabessa in Afaan Oromoo. ${ }^{23,33}$ It has been found in Ethiopia's most floristic regions as well as Eritrea, but it is unknown outside of the Horn of Africa. ${ }^{34}$ In Ethiopia, different components of Crinum abyssinicum are traditionally used to treat a variety of diseases other than diabetes, including as wounds, cancroids, hypertension, diabetes, haemorrhage, hepatitis $\mathrm{B}$, skin infection, and several types of tumors; ${ }^{23,33,35}$ roots for hepatitis-B and hemorrhage $;^{33}$ leaves for skin infection and swelling and cancer (tumor); ${ }^{36}$ roots and bulbs for snakebite ${ }^{37}$ and earache; ${ }^{38}$ bulbs for rheumatoid; ${ }^{38}$ an evil spirit. ${ }^{32}$

Despite Ethiopian traditional medicine's usage of this medicinal plant to treat diabetes and the aforementioned condition, no scientific study has been conducted. As a result, the goal of this study is to see if the traditional usage of Crinum abyssinicum shoot tips to treat diabetes has any scientific backing.

\section{Methods}

\section{Drugs and Chemicals}

The following drugs, chemical supplies, and instruments were utilized; Streptozotocin (Fisco Research laboratories), glibenclamide (Julphar Pharmaceuticals, Ras Al Khaimah, UAE), citric acid monohydrate (Lab Tech Chemicals, Mumbai, India), trisodium citrate dihydrate (Blulux Laboratories, Faridabad, India), ethanol absolute (Nice chemical, India), halothane (Primal Enterprises, India), 40\% glucose solution (Reyoung Pharmaceuticals, Shandong, China), distilled water, hydrochloric acid and ferric chloride (BDH Laboratory Supplies Poole, England), acetic anhydride and Mayer's reagent (May and Baker LTD Dagenham, England), and sulfuric acid (Fisher Scientific, UK), sodium hydroxide (BDH, chemical lab, England).

\section{Collection and Preparation of the Extract}

Crinum abyssinicum fresh shoot tips were obtained in the Sinan district of Ethiopia's East Gojjam Zone, near Debre Markos. During shipment, the plant material was wrapped in plastic sheets and authenticated by Mr. Abiyu Enyew, a botanist at the University of Gondar's Biology Department. With voucher number 001BAT/2019, a voucher specimen was deposited in the herbarium of the University of Gondar's Department of Biology for future reference. The plant shoot tips were cleansed with tap water after collecting and air-dried at room temperature in the shade with enough ventilation. After that, the size was reduced to a reasonably coarse powder using a mortar and pestle. A sensitive digital weighing balance was used to weigh the powdered plant ingredients. The extraction was carried out in an Erlenmeyer flask for 3 days at room temperature using 6 litters of hydro-alcoholic for $575 \mathrm{~g}$ of moderately powdered shoot tips (10:1 $\mathrm{v} / \mathrm{w})$ solvent to dry weight ratio. ${ }^{39}$ The extraction process was aided by periodic shaking, and the extract was subsequently filtered using muslin cloth and Whatman filter paper No.1 The residue was re-macerated for 3 days by repeating the process three times with the same volume of solvent to completely extract the plant material, and the filtrates were dried in a hot air oven at a temperature of not more than $40^{\circ} \mathrm{C}$. The dried shoot tips extract was then preserved in a desiccator until it was needed.

\section{Experimental Animals}

Swiss albino mice were used, which were bred at the University of Gondar's School of Pharmacy, College of Medicine and Health Sciences' animal house facilities. Because male mice are more compatible and sensitive than female mice, the researchers utilized healthy male mice weighing $25-35$ grams (8-12 weeks) in the investigation. According to a recent study, female mice with a body weight of 25-35 grams (8-12 weeks) were recommended for acute oral toxicity testing. ${ }^{40,41}$ The mice were kept in a regular environment (six mice per polypropylene cage) with a 12-hour light/12- 
hour dark cycle and unlimited access to standard pellets and water. Throughout the experiment, they were cared for and managed according to the international criteria for the use and maintenance of experimental animals provided by the Organization for Economic Cooperation and Development (OECD) and the Institute for Laboratory Animal Research (ILAR). The mice were randomized at room temperature and given one week to acclimate to the laboratory surroundings before beginning the treatments. Mice were sacrificed painlessly and humanely via cervical dislocation at the end of each experiment, and then buried in the college's disposal area. ${ }^{42,43}$

\section{Preliminary Phytochemical Screening Tests of Crude Extracts of Crinum abyssinicum}

The crude extract of Crinum abyssinicum shoot tips was subjected to qualitative tests for identification of different phytochemical constituents (secondary metabolites) such as alkaloids, phenolic compounds, glycosides, cardiac glycosides, flavonoids, saponins, tannins, steroidal compounds, terpenoids, and anthraquinones using standard chemicals used for qualitative preliminary phytochemical screening tests with minor modifications. ${ }^{44}$

\section{Acute Oral Toxicity Test}

Before beginning the entire study, a preliminary acute oral toxicity test was done on the crude extract, following the limit test instructions of the Organization for Economic Cooperation and Development (OECD) No 425 Guideline to rule out any signs of toxicity. Five female albino mice (one animal step wisely) were chosen at random after a week of acclimating. Initially, a single healthy female mouse was fasted for 4 hours (except, water). The extract was subsequently given orally at a dose of $2000 \mathrm{mg} / \mathrm{kg}$. Following that, it was closely monitored for 24 hours for any physical or behavioral changes, with special care paid for in the first 4 hours following administration. The remaining four healthy female mice were chosen based on the results of the first mouse.

\section{Grouping and Dosing of Animals}

To depict the variability exhibited in human diabetic patients, it is advantageous to employ more than one animal model. As a result, four distinct diabetes models were used: normoglycemic, oral glucose loaded, single and repeated dosage STZ-induced diabetic models. Mice were randomly allocated to five groups in the normoglycemic and oral glucose loading scenarios (6 mice per group). Group I (negative control) received $10 \mathrm{~mL} / \mathrm{kg}$ distilled water (DW); Group II (positive control) received the standard medicine glibenclamide (GLC5mg/kg); and Groups III-V (test groups) received Crinum abyssinicum crude extract at concentrations of $100 \mathrm{mg} / \mathrm{kg}, 200 \mathrm{mg} / \mathrm{kg}$, and $400 \mathrm{mg} / \mathrm{kg}$, respectively. The dose values were determined using the OECD 425 acute oral toxicity data. ${ }^{45}$

There were five different diabetic test groups (groups I-V) in a single-dose STZ induced diabetic animal model: diabetic negative control group (group I) was treated with vehicle (DW); diabetic positive control group (group IIIV) was treated with standard drug (GLC5 $\mathrm{mg} / \mathrm{kg}$ ); and diabetic positive control group (group III) was treated with different doses of Crinum abyssinicum crude extract $(100 \mathrm{mg} / \mathrm{kg}, 200 \mathrm{mg} / \mathrm{kg}$, and $400 \mathrm{mg} / \mathrm{kg} \mathrm{CACE})$. The goal of this model is to determine the link between the crude extract's blood glucose reducing actions and the passage of time.

Mice were randomly assigned into six groups in the repeated-dose STZ produced diabetic paradigm (five groups of diabetic mice and one additional group of normal mice) (six mice per group). Group I (diabetes negative control) received $10 \mathrm{~mL} / \mathrm{kg}$ DW; Group II (diabetic positive control) received GCL $5 \mathrm{mg} / \mathrm{kg}$; and Groups III-V (diabetic test groups) received various doses of Crinum abyssinicum crude extract (100 mg/kg, $200 \mathrm{mg} / \mathrm{kg}$, and $400 \mathrm{mg} / \mathrm{kg} \mathrm{CACE})$. $10 \mathrm{~mL} / \mathrm{kg}$ DW was given to Group VI (normal negative control). This model was created to investigate the extract's long-term effects on body weight and lipid profiles in a time-dependent manner.

The hypoglycemic drug glibenclamide was chosen as a reference drug because sulfonylureas are known to stimulate insulin secretion from existing pancreatic beta cells in the streptozotocin (STZ) diabetic rodent model and to compare the efficacy of a variety of glucose-lowering compounds via increased activity of pancreatic $\beta$-cells, resulting in the secretion of larger amounts of insulin. ${ }^{46-49}$ The study was conducted utilizing the oral method of administration since, as previously stated, people generally utilize orally. The following calculation was used to compute the percentage reduction in BGL: 


$$
(\%) \text { reduction in } \mathrm{BGL}=\frac{\mathrm{BGL} \text { at basline }-\mathrm{BGL} \text { on } 14^{\text {th }} \text { day } * 100}{\mathrm{BGL} \text { at baseline }}
$$

\section{Measurement of Blood Glucose Level}

Blood samples were withdrawn aseptically by snipping the tip of the tail in all animal models to assess the blood glucose level (BGL). BGL was tested with a glucometer in triplicates, with the average value being used. ${ }^{50}$

\section{The Effect of Crude Extract on Normoglycemic Mice}

Healthy normal mice were fasted for 14 hours, with water available ad libitum. After that, they were divided into five groups at random (six mice per group). Mice were grouped and treated as previously reported. All mice's BGL was assessed before treatment (at $\mathrm{t}=0$ hours as a baseline), then at $1,2,4$, and $6 \mathrm{~h}$ after treatment. ${ }^{51}$

\section{The Effect of Crude Extract on Oral Glucose Tolerance Tests}

Healthy normal mice were fasted for 14 hours, with water available ad libitum. After that, they were divided into five groups at random (six mice per group). Each mouse was given a $2000 \mathrm{mg} / \mathrm{kg}$ body weight glucose solution orally 30 minutes before the extract was given. They were then administered extract doses orally in accordance with their different groups. Each animal's BGL was tested before treatment (at $\mathrm{t}=0 \mathrm{~h}$ as a baseline), then at $0.5,1$, and $2 \mathrm{~h}$ after glucose injection. ${ }^{52}$

\section{Induction of Experimental Diabetes}

STZ, dissolved in a $0.1 \mathrm{M}$ cold citrate buffer $(\mathrm{pH}=4.5)$, was used to induce diabetes. To identify the proper dose range, pretests were performed at $60 \mathrm{mg} / \mathrm{kg}, 90 \mathrm{mg} / \mathrm{kg}$, and $150 \mathrm{mg} / \mathrm{kg}$ body weight. A single dosage of $150 \mathrm{mg} / \mathrm{kg}$ freshly produced solution was administered intra-peritoneally to overnight fasted mice depending on the results of the pretest (for 14 hours). Animals were given free access to food and water thirty minutes after being given STZ. After 6 hours of STZ administration, the animals were given a 5\% glucose solution for the next 24 hours to prevent hypoglycemia shock caused by hyper-insulinemia. After three days of induction, the animals were tested for diabetes. The mice with a fasting BGL of more than $200 \mathrm{mg} / \mathrm{dl}$ were then included in the research. STZ-induced diabetic rats were randomly assigned to separate groups to experiment immediately after the screening. To reduce wetness caused by polyuric diabetic mice, the cage bedding was replaced daily. ${ }^{47,53}$

\section{Effect of Single Dose of Crude Extract on Streptozotocin-Induced Diabetic Mice}

After overnight fasting (for 14 hours), STZ-induced diabetic mice were assigned randomly into five different groups (six diabetic mice per group) then mice were treated with vehicle, standard drug, and crude extract of Crinum abyssinicum according to their respective groups as already described above. BGL was measured just before treatment (at $0 \mathrm{~h}$ ) as a baseline, and then at $2,4,6$, and $8 \mathrm{~h}$ post-treatment. ${ }^{54}$

\section{Effect of Repeated Dose Crude Extract on Streptozotocin-Induced Diabetic Mice}

After successfully developing STZ-induced diabetes, the experimental animals were divided into six groups (six mice per group). The vehicle, standard drug, and crude extract were administered once daily for 14 days as the protocol described above. The fast BGL and body weights were measured just before treatment (day 0), 7th, and 14th day. ${ }^{55,56}$

\section{Effects of Crude Extract on Serum Lipid Level of Diabetic Mice}

On the 15th day, a blood sample was taken from overnight fasted (for 14 hours) diabetic mice using a sterile tube after cardiac puncturing under halothane anaesthesia. ${ }^{57}$ The blood samples were left at room temperature for 2 hours before being centrifuged for 15 minutes at $2500 \mathrm{rpm}$ at $30^{\circ} \mathrm{C}$. The supernatant was removed from the pellet immediately to create serum samples for automated chemistry analyzer analysis of serum triglyceride (STG), serum total cholesterol (STC), high-density lipoprotein (HDL), and low-density lipoprotein (LDL). 


\section{Statistical Analysis}

All statistical analyses were carried out with SPSS version 23 statistical program for social science. For six mice in each group, the data were reported as mean \pm standard error of the mean (S.E.M). One-way analysis of variance (ANOVA) was used to compare the means of all parameters across groups and within groups, followed by Tukey's post hoc multiple comparison tests. Statistical significance was defined as a $P$-value of less than 0.05 .

\section{Results}

\section{Yields}

The extraction of 575 grams of Crinum abyssinicum shoot tips yielded 105 grams of crude extract. The percentage yield of Crinum abyssinicum shoot tips hydro-alcoholic crude extract was reported to be $18.26 \%$ (w/w).

\section{Acute Oral Toxicity Tests}

Within the first 24 hours and up to 14 days of observation, a $2000 \mathrm{mg} / \mathrm{kg}$ dose of hydro-alcoholic crude extracts of Crinum abyssinicum shoot tips did not show any signs of toxicity such as restlessness, motor activity, respiration, or diarrhea. To put it another way, all mice survived for the first 24 hours and up to 14 days in the cage. As a result, the median lethal dose (LD50) of the extract required to kill $50 \%$ of the animals is larger than $2000 \mathrm{mg} / \mathrm{kg}$, implying a good safety margin.

\section{Preliminary Phytochemical Screening Tests}

Preliminary phytochemical analysis was performed on crude extracts of Crinum abyssinicum shoot tips using color generating and precipitating chemical reagents, which verified the existence of phytochemical elements (Table 1).

\section{Effect of Crude Extract on Normoglycemic Mice}

Table 2 shows the findings of hydro-alcoholic crude extracts of Crinum abyssinicum shoot tips in normoglycemic mice. During the first hour after administration, there were no statistically significant variations in BGL among the treatment groups. CACE $100 \mathrm{mg} / \mathrm{kg}$ had no effect on blood sugar levels. When compared to mice receiving DW $10 \mathrm{ml} /$ $\mathrm{kg}$, the other doses showed a substantial reduction commencing at different time points: $2 \mathrm{nd} \mathrm{h}(\mathrm{p}<0.01)$ for $400 \mathrm{mg} /$ $\mathrm{kg}$ and 4th $\mathrm{h}(\mathrm{p}<0.01)$ for $200 \mathrm{mg} / \mathrm{kg}$; 6th $\mathrm{h}(\mathrm{p}<0.001)$ for both $200 \mathrm{mg} / \mathrm{kg}$ and $400 \mathrm{mg} / \mathrm{kg}$. At these time points, the hypoglycemia induced was much lower than the standard $(\mathrm{p}<0.01)$. Treatment with GLC $5 \mathrm{mg} / \mathrm{kg}$ lowered BGL considerably ( $\mathrm{p}<0.001$ ), with percentage reductions of $10.28 \%$ at the $2 \mathrm{nd} \mathrm{h}, 33.87 \%$ at the 4 th $\mathrm{h}$, and $44.96 \%$ at the 6th h compared to baselines (fasting BGL). CACE $200 \mathrm{mg} / \mathrm{kg}$ resulted in significant BGL reductions $(\mathrm{p}<0.01)$ and ( $p<0.001)$ during the 4 th and 6th hours, with percentage reductions of $12.57 \%$ and $15.57 \%$, respectively. CACE $400 \mathrm{mg} / \mathrm{kg}$, on the other hand, demonstrated a significant BGL reduction $(\mathrm{p}<0.01)$ with a percentage decrease of $9.79 \%$ at the $2 \mathrm{nd} h$ and $(\mathrm{p}<0.001)$ with percentage reductions of 27.19 and $38.40 \%$ at the 4 th and 6 th $\mathrm{h}$, respectively.

\section{Effect of Crude Extract on Oral Glucose Loaded Mice}

Table 3 shows the effects of Crinum abyssinicum shoot tips crude extract on Oral Glucose Loaded Non-Diabetic Mice. The BGL reached its maximum level at $0.5 \mathrm{~h}$ after an oral glucose challenge with a dose of $2000 \mathrm{mg} / \mathrm{kg}$ in non-diabetic mice. The BGL was significantly lowered with the tested doses of $100 \mathrm{mg} / \mathrm{kg}(\mathrm{p}<0.05)$ at the 1 st and $2 \mathrm{nd} \mathrm{h,} 200 \mathrm{mg} / \mathrm{kg}$ $(\mathrm{p}<0.01)$ and $(\mathrm{p}<0.001)$ at the 1 st and $2 \mathrm{nd} \mathrm{h}$, respectively. However, as compared to the negative control, the tested dose of $400 \mathrm{mg} / \mathrm{kg}$ and the GLC $5 \mathrm{mg} / \mathrm{kg}$ resulted in a substantial improvement in BGL $(\mathrm{p}<0.001)$ at both the 1st and 2nd $\mathrm{h}$. Intra-group analysis, on the other hand, revealed that oral glucose loading results in a statistically significant drop in BGL at the 1st and 2nd hour.

\section{Effect of Single Dose Crude Extract on Streptozotocin-Induction of Diabetes}

In this study, seventy-six mice were given a $150 \mathrm{mg} / \mathrm{kg}$ dosage of STZ intra-peritoneal injection and were determined to be diabetic (fasting BGL $>200 \mathrm{mg} / \mathrm{dl}$ ) 3 days after the injection, with a success rate of $72.37 \%$. Six mice died before the extract was administered, while the others lived to see the end of the trial. Table 4 shows the results of the anti- 
Table I The Phytochemical Screening of Crude Extract of the Shoot Tips of Crinum abyssinicum

\begin{tabular}{|l|l|l|l|}
\hline S/No & Phytochemical & Tests Carried Out & Observation \\
\hline $\mathbf{I}$ & Alkaloids & $\begin{array}{l}\text { a. Mayer's reagent } \\
\text { b. Wagner's reagent }\end{array}$ & + \\
\hline $\mathbf{2}$ & Flavonoids & $\begin{array}{l}\text { a. Alkaline reagent } \\
\text { b. Lead acetate test } \\
\text { c. Ammonia test }\end{array}$ & + \\
\hline $\mathbf{3}$ & Phenols & $\begin{array}{l}\text { a. Alkaline reagent } \\
\text { b. Lead acetate test } \\
\text { c. Ferric chloride }\end{array}$ & + \\
\hline $\mathbf{4}$ & Tannins & $\begin{array}{l}\text { a. Iron salts test } \\
\text { b. Lead acetate test } \\
\text { c. Ferric chloride }\end{array}$ & + \\
\hline $\mathbf{5}$ & Saponins & $\begin{array}{l}\text { a. Foam } \\
\text { b. I0\%NaNO } 3 \text { test }\end{array}$ & + \\
\hline $\mathbf{6}$ & Steroid & a. Salkowski's test & + \\
\hline $\mathbf{7}$ & Glycosides & $\begin{array}{l}\text { a. Liebermann's test } \\
\text { b. Salkowski's test }\end{array}$ & + \\
\hline $\mathbf{8}$ & Anthraquinones & $\begin{array}{l}\text { a. Bontrager's test } \\
\text { b. Modified Bontrager's }\end{array}$ & + \\
\hline $\mathbf{9}$ & $\begin{array}{l}\text { a. Liebermann Burchard's reagent } \\
\text { b. Keller-Kiliani reaction }\end{array}$ & + \\
\hline & a. Chloroform plus sulphuric acid & + \\
\hline
\end{tabular}

Notes: $(+)$ Indicates the presence and (-) Indicates the absence of secondary metabolite.

hyperglycemic impact of Crinum abyssinicum hydro-alcoholic crude extract on STZ-induced diabetes. When groups receiving the plant extract were compared, there was no statistically significant variability between baselines (fasting BGL) across all groups and at all-time points. In all doses of crude extract, the intra-group analysis revealed no statistically significant BGL reduction. Nonetheless, when compared to the corresponding fasting BGL, the percentage reduction in BGL was determined to be $11.22 \%$ with CACE $400 \mathrm{mg} / \mathrm{kg}$ and $17.24 \%$ with GLC $5 \mathrm{mg} / \mathrm{kg}$ treated group at the 8th hour. When compared to the negative control, GLC $5 \mathrm{mg} / \mathrm{kg}$ resulted in statistically significant BGL reductions

Table 2 Effect of the Crude Extract on Normoglycemic Mice

\begin{tabular}{|c|c|c|c|c|c|}
\hline \multirow[t]{2}{*}{ Group } & \multicolumn{5}{|c|}{ Blood Glucose Level (mg/dl) at Different Time Intervals } \\
\hline & $\mathbf{O} \mathbf{h}$ & I h & $2 \mathbf{h}$ & $4 \mathrm{~h}$ & $6 \mathrm{~h}$ \\
\hline DW 10 & $83.17 \pm 0.401$ & $81.33 \pm 0.49$ & $78.33 \pm 0.422$ & $77.33 \pm 0.494$ & $75.17 \pm 0.401$ \\
\hline GLC 5 & $82.67 \pm 0.333$ & $78.83 \pm 0.307^{\delta \mathrm{B}}$ & $74.17 \pm 0.307^{\alpha B, \delta C, \beta C, \gamma B}$ & $54.67 \pm 0.76^{\alpha C, \delta C, \beta C, \gamma C}$ & $45.50 \pm 0.764^{\alpha C, \delta C, \beta C, \gamma C}$ \\
\hline CACEIOO & $83.83 \pm 0.477$ & $80.67 \pm 0.422$ & $78.67 \pm 0.494^{\varepsilon \mathrm{C}}$ & $75.67 \pm 0.558^{\delta \mathrm{A}, \varepsilon \mathrm{C}}$ & $74.00 \pm 0.683^{\delta \mathrm{A}, \varepsilon \mathrm{C}}$ \\
\hline CACE200 & $83.50 \pm 0.428$ & $79.50 \pm 0.428$ & $77.00 \pm 0.577^{\mu \mathrm{B}, \delta \mathrm{A}}$ & $73.00 \pm 0.816^{\alpha B,} \delta B, \varepsilon C$ & $70.50 \pm 0.719^{\alpha C,} \delta C, \varepsilon C$ \\
\hline CACE400 & $83.33 \pm 0.422$ & $79.50 \pm 0.563$ & $75.17 \pm 0.477^{\alpha \mathrm{B}, \delta \mathrm{C}, \beta \mathrm{B}}$ & $60.67 \pm 0.667^{\alpha C,} \delta C, \beta C, \gamma C$ & $51.33 \pm 0.615^{\alpha C, \delta C, \beta C, \gamma C}$ \\
\hline
\end{tabular}

Notes: Results are expressed as mean \pm S.E.M, ( $n=6$ mice per group) and analyzed by one-way ANOVA followed by Post Hoc Tukey's test. ${ }^{\alpha}$ Compared with negative control group; ${ }^{\beta}$ Compared with CACE I00mg/kg; ${ }^{\gamma}$ Compared with CACE200mg $/ \mathrm{kg} ;{ }^{8}$ Compared with fasting blood glucose level; ${ }^{\varepsilon} \mathrm{Compared}$ with GLC5; ${ }^{A} \mathrm{P}<0.05,{ }^{\mathrm{B}} \mathrm{P}<0.0 \mathrm{I}$, $c_{p}<0.001$.

Abbreviations: DW, distilled water; GLC, glibenclamide; CACE, crinum abyssinicum crude extract. 
Table 3 Effect of the Crude Extract on Oral Glucose Loaded Mice

\begin{tabular}{|c|c|c|c|c|}
\hline \multirow[t]{2}{*}{ Group } & \multicolumn{4}{|c|}{ Blood Glucose Level $(\mathrm{mg} / \mathrm{dl})$ at Different Time Intervals } \\
\hline & 0 Hours & 0.5 Hours & I Hours & 2 Hours \\
\hline DWIO & $82.50 \pm 0.428$ & $190.50 \pm 0.428^{\delta C}$ & $156.50 \pm 1.057^{\delta C, \varepsilon B}$ & $127.67 \pm 2.124^{\delta \mathrm{B}, \varepsilon \mathrm{C}}$ \\
\hline GLC5 & $82.33 \pm 0.558$ & $170.17 \pm 0.749^{\alpha c, \beta C, \gamma C, \delta C, \zeta C}$ & $90.83 \pm 1.014^{\alpha C, \beta C, \gamma C, \delta C, \zeta C}$ & $61.00 \pm 1.291^{\alpha C, \beta C, \gamma C, \delta C, \zeta C}$ \\
\hline CACEIOO & $82.50 \pm 0.563$ & $191.00 \pm 0.632^{\varepsilon C, \delta C}$ & $153.00 \pm 0.577^{\alpha \mathrm{A}, \varepsilon \eta, \delta \mathrm{C}}$ & 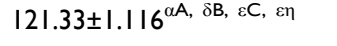 \\
\hline CACE200 & $82.67 \pm 0.333$ & $190.00 \pm 0.365^{\varepsilon \eta, \delta C}$ & $|5| .50 \pm 0.428^{\alpha B, \varepsilon C, \varepsilon \eta, \delta C}$ & $82.33 \pm 0.882^{\alpha C, \varepsilon C, \varepsilon \eta, \delta C}$ \\
\hline CACE400 & $82.00 \pm 0.516$ & $187.67 \pm 0.803^{\alpha A, \mu C, \delta C}$ & $149.83 \pm 0.601^{\alpha C,} \zeta \mathrm{C}, \eta \mathrm{C}, \delta \mathrm{C}$ & $80.50 \pm 0.847^{\alpha C, \varepsilon C, \varepsilon \eta, \delta C}$ \\
\hline
\end{tabular}

Notes: Results are expressed in mean \pm S.E.M, ( $n=6$ mice per group) and analyzed by one-way ANOVA followed by Post Hoc Tukey's test. ${ }^{\alpha}$ Compared with negative control group; ${ }^{\beta}$ Compared with CACE $100 ;{ }^{\gamma}$ Compared with CACE200; ${ }^{\delta}$ Compared with CACE $400 ;{ }^{\varepsilon}$ Compared with blood glucose level at 0.5 hrs; ${ }^{\zeta}$ Compared with fasting blood glucose level; ${ }^{7}$ Compared with glibenclamide $5 \mathrm{mg} / \mathrm{kg} ;{ }^{A} \mathrm{p}<0.05,{ }^{\mathrm{B}} \mathrm{p}<0.0 \mathrm{I},{ }_{\mathrm{P}}<0.001$.

Abbreviations: DW, distilled water; GLC, glibenclamide; CACE, crinum abyssinicum crude extract.

Table 4 Effect of Single-Dose Crude Extract on Streptozotocin-Induction of Diabetes

\begin{tabular}{|c|c|c|c|c|c|}
\hline \multirow[t]{2}{*}{ Group } & \multicolumn{5}{|c|}{ Blood Glucose Level (mg/dl) at Different Time Intervals (Hour) } \\
\hline & $\mathbf{0}$ & 2 & 4 & 6 & 8 \\
\hline DWIO & $284.50 \pm 2.04$ & $283.00 \pm 2.206$ & $282.83 \pm 1.52$ & $281.50 \pm 2.53$ & $282.00 \pm 2.25$ \\
\hline GLC5 & $286.17 \pm 2.51$ & $278.83 \pm 2.01$ & $267.33 \pm 1.4 I^{\alpha B, \delta A}$ & $251.17 \pm 1.99^{\alpha C, \delta B}$ & $236.83 \pm 2.68^{\alpha C, \delta C}$ \\
\hline CACEIOO & $285.33 \pm 2.87$ & $282.83 \pm 2.30$ & $280.67 \pm 2.231$ & $278.67 \pm 2.25$ & $277.33 \pm 2.25$ \\
\hline CACE200 & $285.33 \pm 2.22$ & $282.33 \pm 2.09$ & $279.17 \pm 1.89$ & $275.33 \pm 2.20$ & $272.17 \pm 2.40$ \\
\hline CACE400 & $285.33 \pm 2.51$ & $279.83 \pm 2.24$ & $268.83 \pm 2.41$ & $264.33 \pm 3.20^{\alpha \mathrm{B}, \delta \mathrm{A}}$ & $253.33 \pm 2.11^{\alpha C, \delta B}$ \\
\hline
\end{tabular}

Notes: Values are expressed as mean \pm SEM ( $n=6$ mice in each group) and analysed with one-way ANOVA followed by Post Hoc Tukey's test; ${ }^{\alpha}$ Compared to the negative control, ${ }^{8}$ Compared with fasting blood glucose level; ${ }^{A} p<0.05,{ }^{B}<<0.01,{ }^{C} p<0.001$.

Abbreviations: DW, Ddstilled water; GLC, glibenclamide; CACE, crinum abyssinicum crude extract.

$(\mathrm{p}<0.01)$ at the 4th, $(\mathrm{p}<0.001)$ at the 6th, and $(\mathrm{p}<0.001)$ at the 8 th $\mathrm{h}$. Similarly, as compared to the negative control, CACE $400 \mathrm{mg} / \mathrm{kg}$ demonstrated statistically significant BGL reduction $(\mathrm{p}<0.01)$ at the 6th hour and $(\mathrm{p}<0.001)$ at the 8th hour. When compared to baseline, GLC $5 \mathrm{mg} / \mathrm{kg}$ resulted in a substantial blood glucose reduction $(\mathrm{p}<0.05)$ at the 4 th and 6th hour, and $(\mathrm{p}<0.01)$ at the 8 th hour (fasting BGL).

\section{Effect of Repeated Doses of Crude Extract on STZ-Induction of Diabetic Mice}

The BGL of normal and diabetic mice was tested once a week after treatment with CACE, DW10, and GLC5. Table 5 summarizes their findings. Diabetic mice demonstrated significant variations in BGL $(p<0.001)$ throughout all time intervals after induction compared to non-diabetic (normal) mice, but no significant differences in baselines (fasting BGL) across all diabetic mouse groups. On the 7th day, treatment doses of CACE100 $\mathrm{mg} / \mathrm{kg}(\mathrm{p}<0.05)$ and CACE $200 \mathrm{mg} / \mathrm{kg}(\mathrm{p}<0.01)$ produced in statistically significant reductions in baselines (fasting BGL) when compared to diabetes control. Similarly, as compared to diabetic control, CACE $400 \mathrm{mg} / \mathrm{kg}$ and GLC $5 \mathrm{mg} / \mathrm{kg}$ result in a substantial reduction in BGL $(\mathrm{p}<0.001)$ on the 7th day. Similarly, as compared to diabetes negative control, CACE $100 \mathrm{mg} / \mathrm{kg}(\mathrm{P}<$ 0.01) and all other treatment groups (CACE $200 \mathrm{mg} / \mathrm{kg}$, CACE $400 \mathrm{mg} / \mathrm{kg}$, and GLC5 $\mathrm{mg} / \mathrm{kg}$ ) cause substantial reductions in baselines (fasting BGL) on the 14th day ( $\mathrm{p}<0.001$ ). On the 14th day, CACE $100 \mathrm{mg} / \mathrm{kg}(6.6 \%)$, CAE $200 \mathrm{mg} / \mathrm{kg}(13.26 \%)$, CACE $400 \mathrm{mg} / \mathrm{kg}$ (23.51\%), and GLC $5 \mathrm{mg} / \mathrm{kg}(37.16 \%)$ showed the greatest percentage reduction in fasting BGLs. CACE $400 \mathrm{mg} / \mathrm{kg}$ significantly reduced BGL $(\mathrm{p}<0.05$ and $\mathrm{p}<0.001)$ on the 7 th and 14th days, respectively, when compared to the baseline (fasting BGL) level, according to the intra-group analysis. On the 7th and 
Table 5 Effect of Repeated Dose of Crude Extract on STZ-Induction of Diabetic Mice

\begin{tabular}{|c|c|c|c|c|c|}
\hline \multirow[b]{2}{*}{ Group } & \multicolumn{3}{|c|}{ Fasting Blood Glucose Level (mg/dl) } & \multicolumn{2}{|c|}{ Percentage Reduction } \\
\hline & BGL $(t=0)$ & 7th Day & I4th Day & 7th Day & I4th Day \\
\hline DNC & $284.50 \pm 2.05^{\alpha C}$ & $283.67 \pm 2.50^{\alpha \mathrm{C}}$ & $282.67 \pm 2.60^{\alpha C}$ & 0.29 & 0.64 \\
\hline GLC5 & $286 .|7 \pm 2.5|^{\alpha C}$ & $194.33 \pm 4.49^{\alpha \mathrm{C}, \zeta C, \delta B}$ & $179.83 \pm 2.52^{\alpha C, \zeta C, \delta C}$ & 32.1 & 37.16 \\
\hline CACEIOO & $285.33 \pm 2.87^{\alpha C}$ & $270.17 \pm 2.40^{\alpha \mathrm{C}, \zeta \mathrm{A}}$ & $266.33 \pm 2.46^{\alpha C}, \zeta B$ & 5.31 & 6.66 \\
\hline CACE200 & $285.33 \pm 2.22^{\alpha C}$ & $265.50 \pm 2.1 I^{\alpha C, \zeta B}$ & $247.50 \pm 2.42^{\alpha C, \zeta C}$ & 6.95 & 13.26 \\
\hline CACE400 & $286.33 \pm 2.5 I^{\alpha C}$ & $238.17 \pm 2.99^{\alpha C}, \zeta C, \delta B$ & $219.00 \pm 3.06^{\alpha C, \zeta C, \delta C}$ & 16.82 & 23.51 \\
\hline NNC & $88.33 \pm 1.89 \zeta C$ & $86.67 \pm 2.22 \zeta C$ & $87.67 \pm 1.93 \zeta C$ & 1.88 & 0.75 \\
\hline
\end{tabular}

Notes: Values are expressed as mean \pm SEM ( $n=6$ mice in each group) and analysed by one-way ANOVA followed by Post Hoc Tukey's test; ${ }^{\zeta}$ Compared to the diabetic control, ${ }^{\alpha}$ compared to the normal control, ${ }^{\delta}$ Compared to baseline; ${ }^{A} \mathrm{p}<0.05,{ }^{B} \mathrm{p}<0.01$, and ${ }^{C} \mathrm{p}<0.00 \mathrm{I}$.

Abbreviations: DNC, diabetic negative control; GLC, glibenclamide; CACE, crinum abyssinicum crude Eetract; NNC, normal negative control.

14th days, however, neither the diabetes negative control group nor the normal control group showed a significant drop in BGL relative to their respective baseline (fasting BGL) levels.

\section{Effect of the Repeated Daily Doses of Crude Extract on Body Weight of Diabetic Mice} The body weight of mice was evaluated 72 hours after STZ injection before extract delivery, and there was no significant difference between diabetic groups, but there was a considerable weight loss when compared to the normal control group. There was no discernible difference in bodyweight between the treatment groups and the usual control group. At the 7th and 14th days of treatment, STZ induced a considerable reduction of body weight in diabetic control compared to normal control (Table 6). On the 7th day of treatment, a statistically significant body weight gain was found with CACE $200 \mathrm{mg} /$ $\mathrm{kg}(\mathrm{p}<0.001)$, and GL5 mg/kg $(\mathrm{p}<0.001)$ as compared to the diabetes control group. CACE $100 \mathrm{mg} / \mathrm{kg}$ also caused a substantial increase in body weight $(\mathrm{p}<0.01)$. When compared to diabetes control, all other doses of crude extract (CACE 200mg/kg), CACE $400 \mathrm{mg} / \mathrm{kg}$, and the reference medicine (GLC5 mg/kg) showed a substantial $(\mathrm{p}<0.001)$ increase in body weight after 14 days. On the other hand, when compared to the normal control group, the diabetes control group's body weight was considerably lower $(\mathrm{p}<0.05$ and $\mathrm{p}<0.001)$ on the 7 th and 14 th days. The intra-group analysis revealed that on the 7th and 14th days of treatment, the CACE $400 \mathrm{mg} / \mathrm{kg}$ and GL5 mg/kg showed a substantial

Table 6 Effect of the Repeated Daily Doses of Crude Extract on Body Weight of Diabetic Mice

\begin{tabular}{|c|c|c|c|c|}
\hline \multirow[t]{2}{*}{ Group } & \multicolumn{4}{|l|}{ Body Weight (g) } \\
\hline & Before Induction & Baseline (0 Day) & 7th Day & I4th Day \\
\hline DNC & $29.18 \pm 0.55$ & $28.68 \pm 0.25$ & $26.54 \pm 0.33^{\alpha \mathrm{B}}$ & $25.98 \pm 0.25^{\alpha C,} \delta \mathrm{A}$ \\
\hline GLC5 & $27.69 \pm 0.66$ & $26.81 \pm 0.54$ & $30.55 \pm 0.70 \zeta \mathrm{C}, \delta \mathrm{A}$ & $31.49 \pm 0.7 I^{\zeta C, \delta B}$ \\
\hline CACEIOO & $28.94 \pm 0.70$ & $27.06 \pm 0.63$ & $25.75 \pm 0.45$ & $29.34 \pm 0.49 \zeta$ В \\
\hline CACE200 & $30.18 \pm 0.75$ & $28.83 \pm 0.67$ & $29.26 \pm 0.47^{\zeta A}$ & $29.58 \pm 0.43 \zeta \subset$ \\
\hline CACE400 & $28.88 \pm 0.46$ & $27.63 \pm 0.30$ & $30.19 \pm 0.33 \zeta \mathrm{C}, \delta \mathrm{A}$ & $31.13 \pm 0.26^{\zeta C, 8 B}$ \\
\hline NNC & $28.48 \pm 0.94$ & $28.74 \pm 0.93$ & $29.5 I \pm 0.89 \zeta \mathrm{A}$ & $30.20 \pm 0.86 \zeta \subset$ \\
\hline
\end{tabular}

Notes: Values are expressed as mean \pm SEM ( $n=6$ mice in each group) and analysed by one-way ANOVA followed by Post Hoc Tukey's test; ${ }^{\zeta}$ Compared to the diabetic control, ${ }^{\alpha}$ Compared to the normal control, ${ }^{\delta}$ Compared to baseline body weight; ${ }^{A} \mathrm{p}<0.05,{ }_{\mathrm{p}}^{\mathrm{B}}<0.0 \mathrm{I}$, and ${ }_{\mathrm{P}}<0.00 \mathrm{I}$.

Abbreviations: DNC, diabetic negative control; GLC, glibenclamide; CACE, crinum abyssinicum crude extract; NNC, normal negative control. 
Table 7 Effect of Repeated Daily Doses of Crude Extract on Lipid Profile of Diabetic Mice

\begin{tabular}{|c|c|c|c|c|}
\hline \multirow[b]{2}{*}{ Group } & \multicolumn{4}{|c|}{ Fasting Blood Glucose Level in (mg/dl) } \\
\hline & STC (mg/dl) & STG (mg/dl) & HDL (mg/dl) & LDL (mg/dl) \\
\hline DNC & $\left.|85.67 \pm| .9\right|^{\alpha C}$ & $171.33 \pm 2.12^{\alpha C}$ & $23.00 \pm 1.13^{\alpha C}$ & $136.33 \pm 2.16^{\alpha C}$ \\
\hline GLC5 & $94.00 \pm 2.37 \zeta \subset$ & $86.00 \pm 2.38 \zeta C$ & $42.00 \pm 1.57 \zeta C$ & $44.17 \pm 2.01 \zeta C$ \\
\hline CACEIOO & $168.17 \pm 2.27^{\zeta C, \alpha C}$ & $161.83 \pm 1.83 \zeta \mathrm{A}, \alpha \mathrm{C}$ & $26.83 \pm 1.54^{\alpha C}$ & $124.50 \pm 2.36^{\alpha C}, \zeta B$ \\
\hline CACE200 & $163.33 \pm 2.72 \zeta \mathrm{C}, \alpha \mathrm{C}$ & $|46.33 \pm 1.9| \zeta C, \alpha C$ & $33.67 \pm 1.75 \zeta \mathrm{B}, \alpha \mathrm{C}$ & $109.17 \pm 1.74 \zeta C, \alpha C$ \\
\hline CACE400 & $153.67 \pm 1.73$ & $|39.67 \pm 1.6|$ & $37.00 \pm 2.32$ & $99.83 \pm 1.74$ \\
\hline NNC & $88.67 \pm .88 \zeta C$ & $82.17 \pm 2.43 \zeta C$ & $38.17 \pm 1.70 \zeta C$ & $33.50 \pm 2.00^{\zeta C}$ \\
\hline
\end{tabular}

Notes: Values are expressed as mean \pm SEM ( $n=6$ mice in each group) and analysed by one-way ANOVA followed by Post Hoc Tukey's test; ${ }^{\zeta}$ Compared to the diabetic control, ${ }^{\alpha}$ Compared to the normal control; ${ }^{A} \mathrm{p}<0.05,{ }^{\mathrm{B}} \mathrm{p}<0.0 \mathrm{I}$, and ${ }^{\mathrm{C}} \mathrm{p}<0.00 \mathrm{I}$.

Abbreviations: DNC, diabetic negative control; GLC, glibenclamide; CACE, crinum abyssinicum crude extract; NNC, normal negative control.

increase in body weight when compared to baseline body weight. CAC $200 \mathrm{mg} / \mathrm{kg}$, on the other hand, exhibited a substantial increase in body weight on the 14th day when compared to baseline.

\section{Effect of Repeated Daily Doses of Crude Extract on Lipid Profile of Diabetic Mice}

Table 7 summarizes the effect of crude extract on lipid profiles. When compared to non-diabetic (normal) mice, there was a substantial increase $(\mathrm{p}<0.001)$ in STC, STG, and LDL cholesterol content and a significant decrease $(\mathrm{p}<0.001)$ in HDL cholesterol content after diabetes induction. On the other hand, when all dosages of crude extract (CACE100mg $/ \mathrm{kg}$, CACE $200 \mathrm{mg} / \mathrm{kg}$, CACE $400 \mathrm{mg} / \mathrm{kg}$, and GLC $5 \mathrm{mg} / \mathrm{kg}$ ) were given orally for 14 days, the contents of STC level decreased significantly $(\mathrm{p}<0.001)$ when compared to diabetes negative controls in a dose-dependent manner. At the end of the treatment period, the amounts of STG were considerably reduced $(\mathrm{p}<0.05)$ with CACE $100 \mathrm{mg} / \mathrm{kg}$ and $(\mathrm{p}<$ 0.001) with CACE $200 \mathrm{mg} / \mathrm{kg}$, CACE $400 \mathrm{mg} / \mathrm{kg}$, and GLC 5mg/kg when compared to diabetes control. In comparison to diabetic controls, HDL content was significantly raised with tested dosages of CACE $200 \mathrm{mg} / \mathrm{kg}(\mathrm{p}<0.01)$, CACE $400 \mathrm{mg} / \mathrm{kg}(\mathrm{p}<0.001)$, and GLC $5 \mathrm{mg} / \mathrm{kg}$ after 14 days of treatment. LDL cholesterol content, on the other hand, was considerably reduced in a dose-dependent manner with CACE $100 \mathrm{mg} / \mathrm{kg}(\mathrm{p}<0.01)$ and CACE $200 \mathrm{mg} / \mathrm{kg}$, CACE $400 \mathrm{mg} / \mathrm{kg}(\mathrm{p}<0.001)$.

\section{Discussion}

Glycuria, hyperglycemia, polyphagia, polydipsia, and body weight loss are all observed in STZ-induced diabetic mouse models. Because this parallels human diabetes, in vivo anti-diabetic effects in mice are usually studied. ${ }^{58}$

In an acute oral toxicity investigation, giving mice a single dose of $2000 \mathrm{mg} / \mathrm{kg}$ of hydro-alcoholic crude extract did not result in any toxicity or mortality under observation. As a result, this study demonstrated that the plant extract's LD50 is larger than $2000 \mathrm{mg} / \mathrm{kg}$, which is consistent with Hussein's 2019 finding that an $80 \%$ methanol extract of Crinum abyssinicum bulbs was non-toxic. ${ }^{59}$

DW $10 \mathrm{ml} / \mathrm{kg}$ had no effect on the blood glucose concentrations of overnight fasted normoglycemic mice on the hypoglycemic activity of the crude extract of Crinum abyssinicum shoot tips. After the second hour of post-treatment, CACE $400 \mathrm{mg} / \mathrm{kg}$ shoot tips extract dosages began to have a substantial hypoglycemic impact in normal fasting mice. Normal mice's BGL was considerably reduced with extract doses of CACE $200 \mathrm{mg} / \mathrm{kg}(\mathrm{p}<0.01)$ at the 4th hour and $(\mathrm{p}<$ $0.001)$ at the 6th hour, as well as CACE $400 \mathrm{mg} / \mathrm{kg}(\mathrm{p}<0.01)$ at the 2 nd hour and $(\mathrm{p}<0.001)$ at the 4th and 6th hours in a dose-dependent manner. Both CACE $200 \mathrm{mg} / \mathrm{kg}$ and CACE $400 \mathrm{mg} / \mathrm{kg}$ extract doses generated substantial hypoglycemic action, which was comparable to GLC $5 \mathrm{mg} / \mathrm{kg}$ at the 6th hour, with a slightly greater significance level detected in the reference medication (GLC $5 \mathrm{mg} / \mathrm{kg}$ ). This could indicate that the extract's active phytochemical ingredients need time to reach a sufficient concentration at the site of action. In normal experimental animals, glibenclamide produces 
hypoglycemia by stimulating insulin release from pancreatic $\beta$-cells and inhibiting glucagon secretion. Flavonoids, terpenoids, alkaloids, saponins, and tannins are phytochemical elements (secondary metabolites) that have been proven to exhibit hypoglycemic activity via an insulin-like effect or to induce insulin production from pancreatic beta-cells. ${ }^{60}$ It is possible that the hypoglycemic impact of the hydro-alcoholic extracts of Crinum abyssinicum shoot tips is due to the presence of one or more of these bioactive components. This suggests that the plant extract's likely mechanism of action is comparable to that of the reference medicine.

The Oral Glucose Tolerance Test (OGTT) is the gold standard for determining the body's glucose tolerance. Because it has a higher sensitivity than fasting plasma glucose, it is the primary diagnostic technique. As a result, it is a commonly recommended test for determining glucose homeostasis. It is particularly useful in instances of diabetes where the fasting BGL is only mildly high, as it is a well-accepted and commonly used assay to examine anti-hyperglycemic activity of numerous medicines and to determine the change in carbohydrate metabolism during post-glucose delivery. ${ }^{61,62}$ It also aids in the diagnosis of diabetes and poor glucose homeostasis by accurately measuring insulin sensitivity, insulin secretion, and cell activity. The OGTT model was utilized to examine this changed carbohydrate metabolism after glucose delivery. ${ }^{62}$ An increase in blood glucose promotes insulin production and, in turn, peripheral glucose consumption. Insulin can drive the increased BGL down to a normal level of in two to three hours, according to physiology. ${ }^{63}$ The BGL reached its maximum level after 0.5 hours after all groups were given $2000 \mathrm{mg} / \mathrm{kg}$ body weight of glucose orally. This determines whether oral glucose loading causes physiologic hyperglycemia. By 0 minutes, there was no statistically significant difference in BGL between the groups, but at 0.5 hours, there was a statistically significant difference in BGL between the groups. Furthermore, the statistical analysis revealed a substantial difference between the groups at the first hour. At the 1st hour, multiple-comparison post-hoc testing demonstrated that GLC5 $\mathrm{mg} / \mathrm{kg}$ resulted in a substantial $(\mathrm{p}<0.001)$ drop in plasma sugar levels when compared to the negative control. Furthermore, multiple comparison posthoc analyses revealed that during the 2nd hour, GLC $5 \mathrm{mg} / \mathrm{kg}$, CACE $200 \mathrm{mg} / \mathrm{kg}$, and CACE $400 \mathrm{mg} / \mathrm{kg}$ showed a substantial $(\mathrm{p}<0.001)$ reduction in BGL compared to the glucose-loaded control group. When compared to the blood glucose level at 0.5 hours, glucose tolerance was considerably improved ( $\mathrm{p}<0.001)$ in GLC $5 \mathrm{mg} / \mathrm{kg}$ and all doses of the crude extract-treated groups starting from the second hour onwards. Mice given crude extract had a higher capability for glucose consumption. A previous study by Al-Ishaq, et al, 2019 reported that the mechanism to reduce postprandial hyperglycemia is by inhibiting carbohydrate hydrolyzing enzymes $\alpha$-amylase, and $\alpha$-glycosidase in the digestive system, thereby preventing postprandial hyperglycemia.

The presence of phytochemicals (secondary metabolites) such as flavonoids may further contribute to Crinum abyssinicum's anti-hyperglycaemic action on the OGTT. Flavonoids have a number of essential metabolic health advantages, including diabetes, obesity, cardiovascular disease, and cancer. They slow the progression of diabetes and its complications by regulating glucose metabolism, hepatic enzyme activity, and lipid profile, inhibiting $\alpha$-amylase and $\alpha$-glycosidase, regenerating pancreatic $\beta$-cells, increasing peripheral glucose utilization, and blocking glucose transporter activity from the intestine. ${ }^{64,65}$ This research demonstrates that the claimed medicinal plant exhibits anti-hyperglycemic and glucose-lowering properties similar to glibenclamide, a drug that secretes insulin from pancreatic $\beta$-cells in $\mathrm{T}_{2} \mathrm{DM}$ patients.

A substantial reduction in fasting BGL of all diabetic mice fed with hydro-alcoholic extract of Crinum abyssinicum and reference medication was seen when compared to diabetic control after a single dose of STZ-generated diabetes model. It is exciting to see that CACE $400 \mathrm{mg} / \mathrm{kg}$ reduced hyperglycemia caused by STZ by $11.22 \%$ after 8 hours after oral delivery. This study was almost identical to a prior publication in which Hagina abyssinica reduced BGL by $13.38 \%$ as reported by Kiflie et al, 2020. ${ }^{66}$ The anti-diabetic activity correlates to GLC $5 \mathrm{mg} / \mathrm{kg}$, as shown in Table 4, and all dosages of the crude showed a dose-dependent reduction in blood glucose levels after oral administration. This could be due to the existence of significant concentrations of key phytochemical constituents(s) in the higher dose $400 \mathrm{mg} / \mathrm{kg}$ of plant extracts, as opposed to the lower $100 \mathrm{mg} / \mathrm{kg}$ and medium $200 \mathrm{mg} / \mathrm{kg}$ dose levels.

The greatest reduction of fasting blood glucose was reported with CACE $400(23.51 \%)$ on the 14th day in the antihyperglycemic action of repeated daily doses of CACE in STZ-induced diabetic mice (Table 5). The outcome was comparable to the reference drug's result, which reduced fasting BGL by $37.16 \%$ on the same day. This study was substantially identical to a recent report by Kiflie et al, 2020, in which crude extract (20.68\%) and GLC5 (35.93\%) were 
shown to be the most effective in lowering BGL. ${ }^{66}$ Even though CACE $200 \mathrm{mg} / \mathrm{kg}$ and CACE $400 \mathrm{mg} / \mathrm{kg}$ showed substantial blood glucose reductions $(\mathrm{p}<0.001)$ when compared to diabetes control on the 14 th day $(9.12 \%$ and $13.26 \%$, respectively), the extract had a dose-dependent effect, which could be because the greater dose is more likely to have a higher concentration of the bio-active ingredients that are responsible for decreasing fasting BGL than the smaller dose. GLC $5 \mathrm{mg} / \mathrm{kg}$ pulls down fasting BGL as a result of plasma membrane depolarization, which is caused by selective blockage of adenosine triphosphate (ATP) sensitive $\mathrm{K}+(\mathrm{KATP})$ channels, activating voltage-gated $\mathrm{Ca}^{2+}$ channels, cytosolic $\left(\mathrm{Ca}^{2+}\right)$, and endogenous insulin secretion from pancreatic $\beta$-cells. ${ }^{67}$ This could indicate that STZ at a dose of $150 \mathrm{mg} / \mathrm{kg}$ intra-peritoneal was insufficient to destroy whole-cells and/or that only a few cells survived to regenerate and release insulin. STZ uptake into pancreatic $\beta$-cells islets causes toxicity through a variety of mechanisms, including nitric oxide (NO) donation and free radical formation, resulting in a significant reduction in the intracellular insulin concentration of these cells. ${ }^{68}$ Due to their antioxidant properties, different plant extract phytochemical constituent(s) have exhibited pancreas $\beta$-cell protecting action. The extract of Crinum abyssinicum was found to have similar antioxidant activity and a cell-protective impact in this investigation. In STZ-induced diabetic mice, the plant extract may have antihyperglycemic action.

Because body weight is the best sign of good health and efficient metabolic balance, the effect of repeated daily administration of Crinum abyssinicum hydro-alcoholic shoot tips extract on body weight change in STZ-induced diabetic mice was investigated (Table 6). Over the course of the investigation, the body weight of normal control mice increased gradually. Increased treatment duration, on the other hand, resulted in a considerable reduction in the body-weight of untreated diabetic mice. This conclusion is consistent with a previous study by Jayaprasad et al, which found a similar reduction in body weight in STZ-induced diabetic mice. In STZ-induced diabetic control mice, significant $(\mathrm{p}<0.001)$ body weight loss was observed. Dehydration, protein breakdown, and muscle atrophy are thought to be the causes of body weight loss in diabetic mice due to the lack of carbohydrates as an energy source and fat catabolism. ${ }^{69}$ These data revealed that after 14 days of therapy, GLC5mg/kg and all doses of the extract-treated mice gained considerable weight $(\mathrm{p}<0.001, \mathrm{p}<0.01)$ in comparison to the diabetes control group and baseline body weight, respectively. The extract's ability to reduce hyperglycemia may be linked to its beneficial effect on body weight loss. The extract's ability to reduce hyperglycemia may be linked to its beneficial effect on body weight loss. In this study, the phytochemical contents of Crinum abyssinicum may aid in body weight gain by decreasing free radical production owing to hyperglycemias, enhancing glucose utilization, and thus preventing muscle atrophy or sparing protein catabolism in extract-treated diabetic mice.

According to the findings, there are clear links between DM coexisting with hyperlipidaemia, DM, and hyperlipidemia, as well as death. ${ }^{70}$ Increased STC, STG, LDL, and HDL levels, as well as decreasing HDL levels, are usually related to diabetes, which leads to the development of cardiovascular illnesses. ${ }^{71}$ The current investigation found a consistent positive connection between hyperglycemia and hyperlipidaemia. Hyperlipidemia makes diabetic people more vulnerable to cardiovascular disease. Due to an accelerated breakdown of lipid and free fatty acids from peripheral deposits in insulin shortage, it is regarded as a complication of diabetes mellitus. This explains why untreated diabetic mice have higher levels of STC, STG, and LDL but lower levels of HDL. Hyperglycemia is also associated with an increase in the contents of lipid profiles such as STC, STG, and LDL, as well as a decrease in the contents of HDL. STZinduced diabetic control mice revealed dramatically increased content in STC, STG, and LDL, as well as decreased HDL, as expected. As shown in Table 7, repeated administration of CACE for 14 days lowered STC, STG, and LDL levels, but increased HDL content in a dose-dependent manner. However, it is unclear whether the crude extract from shoot tips was directly involved in lipid metabolism or whether the anti-hyperlipidaemic effect was achieved only as a result of reduced hyperglycemia. In STZ-induced diabetic rats, Centratherum anthelminticum ethanolic seeds extract exhibited a significant reduction in BGL, STC, STG, and LDL, as well as an increase in HDL levels. ${ }^{72}$

\section{Conclusions}

To summarize, this is the first preliminary phytochemical and pharmacological study of Crinum abyssinicum shoot tips. It can be concluded from the findings of this study that the plant extract is safe for mice. According to preliminary findings, the crude extract can significantly lower blood glucose levels in diabetic, normoglycemic, and oral glucose-loaded mice. 
Furthermore, in diabetic mice treated with plant extracts, a reduction in weight loss and hyperlipidemia was seen. These findings provide scientific evidence for the plant's stated usage in Ethiopian folk medicine to treat diabetes mellitus. Further research into the mechanism of this plant's anti-diabetic properties should be conducted using quantitative phytochemical screening tests, in vitro anti-oxidant tests, and histopathological tests. Furthermore, bioactivity-guided research is required to isolate the lead molecule responsible for anti-diabetic activity.

\section{Abbreviations}

ANOVA, Analysis of Variance; BGL, blood glucose level; HDL, high-density lipoprotein; LDL, low-density lipoprotein; $\mathrm{LD}_{50}$, median lethal dose; OECD, Organization for Economic Cooperation and Development; OGTT, oral glucose tolerance test; STZ, streptozotocin; STC, total cholesterol; STG, Serum triglycerides; VLDL, very-low-density lipoprotein.

\section{Data Sharing Statement}

The majority of the data are included in this manuscript. Further data can be found from the corresponding author based on reasonable request.

\section{Ethics Approval and Consent to Participate}

The proposal of the study was submitted and approved by the ethical review committee of the Department of Pharmacology, School of Pharmacy, College of Medicine and Health Sciences, University of Gondar before the commencement of the study. A letter of clearance was obtained with reference number Sop/285/12 on March 16, 2020. In addition, all possible steps were taken to avoid animal suffering during the experiment. However, no consent was needed for this study.

\section{Acknowledgment}

The authors would like to acknowledge the University of Gondar for material support and for allowing to use the laboratory facility.

\section{Disclosure}

The authors declare that they have no conflicts of interest for this work.

\section{References}

1. Tan SY, Wong JLM, Sim YJ, et al. Type 1 and 2 diabetes mellitus: a review on current treatment approach and gene therapy as potential intervention. Diabetes Metab Syndr. 2019;13(1):364-372. doi:10.1016/j.dsx.2018.10.008

2. Vijayaraghavan K. Treatment of dyslipidemia in patients with type 2 diabetes. Lipids Health Dis. 2010;9:144. doi:10.1186/1476-511X-9-144

3. Punthakee Z, Goldenberg R, Katz P. Definition, classification and diagnosis of diabetes, prediabetes and metabolic syndrome. Can J Diabetes. 2018;42:S10-S15. doi:10.1016/j.jcjd.2017.10.003

4. Bishu KG, Jenkins C, Yebyo HG, Atsbha M, Wubayehu T, Gebregziabher M. Diabetes in Ethiopia: a systematic review of prevalence, risk factors, complications, and cost. Obes Med. 2019;15:100132. doi:10.1016/j.obmed.2019.100132

5. Luo Q, Cai Y, Yan J, Sun M, Corke H. Hypoglycemic and hypolipidemic effects and antioxidant activity of fruit extracts from Lycium barbarum. Life Sci. 2004;76(2):137-149. doi:10.1016/j.lfs.2004.04.056

6. Saeedi P, Petersohn I, Salpea P, et al. Global and regional diabetes prevalence estimates for 2019 and projections for 2030 and 2045: results from the International Diabetes Federation Diabetes Atlas. Diabetes Res Clin Pract. 2019;157:107843. doi:10.1016/j.diabres.2019.107843

7. Endris T, Worede A, Asmelash D. Prevalence of diabetes mellitus, prediabetes and its associated factors in Dessie Town, Northeast Ethiopia: a community-based study. Diabetes Metab Syndr Obes. 2019;12:2799-2809. doi:10.2147/DMSO.S225854

8. Zekewos A, Loha E, Egeno T, Wubshet K, Merga Z. Prevalence of diabetes mellitus and associated factors in Southern Ethiopia: a community based study. Ethiop J Health Sci. 2018;28(4):451-460. doi:10.4314/ejhs.v28i4.11

9. Williams R, Karuranga S, Malanda B, et al. Global and regional estimates and projections of diabetes-related health expenditure: results from the International Diabetes Federation Diabetes Atlas, 9th edition. Diabetes Res Clin Pract. 2020;162:108072. doi:10.1016/j.diabres.2020.108072

10. Osadebe P, Odoh U, Uzor P. Natural products as potential sources of antidiabetic drugs. Br J Pharm Res. 2014;4:2075-2095. doi:10.9734/BJPR/ 2014/8382

11. Razavi-Nematollahi L, Ismail-Beigi F. Adverse effects of glycemia-lowering medications in type 2 diabetes. Curr Diab Rep. 2019;19(11):132. doi:10.1007/s11892-019-1266-7

12. Razafindrakoto ZR, Donno D, Tombozara N, et al. Antioxidant, anti-inflammatory, and antidiabetic activities of leaves and stems of Uapaca bojeri Bail. (EUPHORBIACEAE), an endemic plant of Madagascar. Pharmaceuticals. 2020;13(4):71. doi:10.3390/ph13040071 
13. Unuofin JO, Lebelo SL. Antioxidant effects and mechanisms of medicinal plants and their bioactive compounds for the prevention and treatment of type 2 diabetes: an updated review. Oxid Med Cell Longev. 2020;2020:1356893. doi:10.1155/2020/1356893

14. Bilanda DC, Bidingha R, Djomeni Dzeufiet PD, et al. Antihypertensive and antidiabetic activities of Erythrina senegalensis DC (Fabaceae) stem bark aqueous extract on diabetic hypertensive rats. $J$ Ethnopharmacol. 2020;246:112200. doi:10.1016/j.jep.2019.112200

15. Aslan M, Orhan N, Orhan DD, Ergun F. Hypoglycemic activity and antioxidant potential of some medicinal plants traditionally used in Turkey for diabetes. J Ethnopharmacol. 2010;128(2):384-389. doi:10.1016/j.jep.2010.01.040

16. Kooti W, Farokhipour M, Asadzadeh Z, Ashtary-Larky D, Asadi-Samani M. The role of medicinal plants in the treatment of diabetes: a systematic review. Electron Physician. 2016;8(1):1832-1842. doi:10.19082/1832

17. Stefanucci A, Luisi G, Zengin G, et al. Discovery of arginine-containing tripeptides as a new class of pancreatic lipase inhibitors. Future Med Chem. 2019;11(1):5-19. doi:10.4155/fmc-2018-0216

18. Andreeva LA, Myasoedov NF, Shubina TA, Grigorieva ME, Ljapina LA. Arginine-containing tripeptide Pro-Arg-Gly is involved in the regulation of the function of anticoagulation and insular systems under persistent hyperglycemia. Bull Exp Biol Med. 2012;153(5):651-654. doi:10.1007/ s10517-012-1789-2

19. Mollica A, Zengin G, Stefanucci A, et al. Nutraceutical potential of Corylus avellana daily supplements for obesity and related dysmetabolism. J Funct Foods. 2018;47:562-574. doi:10.1016/j.jff.2018.06.016

20. Mollica A, Zengin G, Locatelli M, et al. An assessment of the nutraceutical potential of Juglans regia L. leaf powder in diabetic rats. Food Chem Toxicol. 2017;107:554-564. doi:10.1016/j.fct.2017.03.056

21. Sabiu S, Madende M, Ajao AA-N, Aladodo RA, Nurain IO, Ahmad JB. Chapter 9 - The Genus Allium (Amaryllidaceae: alloideae): features, phytoconstituents, and mechanisms of antidiabetic potential of Allium cepa and Allium sativum. In: Watson RR, Preedy VR, editors. Bioactive Food as Dietary Interventions for Diabetes (Second Edition). Academic Press; 2019:137-154.

22. Bjorå CS, Kwembeya EG, Bogner J, Nordal I. Geophytes diverging in rivers-a study on the genus Crinum, with two new rheophytic taxa from Cameroon. Taxon. 2009;58(2):561-571. doi:10.1002/tax.582020

23. Abebe D, Debella A, Urga K. Medicinal plants and other useful plants of Ethiopia;2003. Nairobi: Camerapix Publishers International; 2003.

24. Ghane SG, Attar UA, Yadav PB, Lekhak MM. Antioxidant, anti-diabetic, acetylcholinesterase inhibitory potential and estimation of alkaloids (lycorine and galanthamine) from Crinum species: an important source of anticancer and anti-Alzheimer drug. Ind Crops Prod. 2018;125:168-177. doi:10.1016/j.indcrop.2018.08.087

25. Chahal S, Lekhak MM, Kaur H, et al. Unraveling the medicinal potential and conservation of Indian Crinum (Amaryllidaceae) species. S Afr J Bot. 2021;136:7-15.

26. Ahmad MH, Singh V, Prasad RK. Preliminary phytochemical screening and antidiabetic activity of extracts of leaves of Crinum Latifolium Linn. Adv Res J Multidiscip Discover. 2018;32(7):35-40.

27. Mvongo C, Mfopa A, Kamgang R, Essame Oyono JL. Antidiabetic and antioxidant activities of crinum jagus extracts on induced diabetes rats MACAPOS 1. Int J Pharmacol Phytochem Ethnomed. 2016;5:86-95. doi:10.18052/www.scipress.com/IJPPE.5.86

28. Senbeta A, Awas T, Gure A. The qualitative and quantitative phytochemical investigation of Crinum Species in Ethiopia. Int $J$ Photochem Photobiol. 2019;3(1):1. doi:10.11648/j.ijpp.20190301.11

29. Regassa R. Assessment of indigenous knowledge of medicinal plant practice and mode of service delivery in Hawassa city, southern Ethiopia. $J$ Med Plants Res. 2013;7(9):517-535.

30. Meresa A, Gemechu W, Basha H, et al. Herbal medicines for the management of diabetic mellitus in Ethiopia and Eritrea including their phytochemical constituents. Am J Adv Drug Deliv. 2017;5(01):040-058.

31. Berihun A, Fekadu N, Geleta B. An ethno botanical review on medicinal plants used for the management of hypertension. J Clin Exp Pharmacol. 2017;7(2):1-6.

32. Kloos H, Menberu T, Tadele A, et al. Traditional medicines sold by vendors in Merkato, Addis Ababa: aspects of their utilization, trade, and changes between 1973 and 2014. Ethiop J Health Dev. 2014;28(2):136-152.

33. Yineger H, Kelbessa E, Bekele T, Lulekal E. Plants used in traditional management of human ailments at Bale Mountains National Park, Southeastern Ethiopia. J Med Plants Res. 2008;2(6):132-153.

34. Sebsebe D, Nordal I. Aloes and Lilies of Ethiopia and Eritrea. Vol. 20. Addis Adaba, Ethiopia: Shama Books; 2010. Available from: https://nhm2. uio.no/botanisk/nbf/temp/Sebsebe\%20et\%20Nordal\%202010\%20Lilies\%20-\%20SCREEN\%2020091220.pdf. Accessed January 20, 2022.

35. Teklehaymanot T, Giday M. Ethnobotanical study of medicinal plants used by people in Zegie Peninsula, Northwestern Ethiopia. $J$ Ethnobiol Ethnomed. 2007;3(1):12. doi:10.1186/1746-4269-3-12

36. Abebe W. An overview of Ethiopian traditional medicinal plants used for cancer treatment. Eur J Med Plants. 2016;14(4):1-16. doi:10.9734/EJMP/ $2016 / 25670$

37. Mekuanent T, Zebene A, Solomon Z. Ethnobotanical study of medicinal plants in Chilga district, Northwestern Ethiopia. J Nat Remedies. 2015 ;15 (2):88-112. doi:10.18311/jnr/2015/476

38. Asmamaw D, Achamyeleh H. Assessment of medicinal plants and their conservation status in case of Daligaw Kebela, Gozamen Werda, East Gojjam Zone. J Biodivers Biopros Dev. 2018;5(1):170. doi:10.4172/2376-0214.1000170

39. Pandey A, Tripathi S. Concept of standardization, extraction and pre phytochemical screening strategies for herbal drug. J Pharmacogn Phytochem. 2014;2(5):115-119.

40. Etuk E. Animals models for studying diabetes mellitus. Agric Biol J N Am. 2010;1(2):130-134.

41. Hammeso WW, Emiru YK, Ayalew Getahun K, Kahaliw W. Antidiabetic and antihyperlipidemic activities of the leaf latex extract of Aloe megalacantha Baker (Aloaceae) in Streptozotocin-induced diabetic model. Evid Based Complement Alternat Med. 2019;2019:1-9. doi:10.1155/ $2019 / 8263786$

42. OECD guidelines for the testing of chemicals, section 4: health effects. Test No. 407: repeated dose 28-day oral toxicity study in rodents. Paris: OECD Publishing; 2008. doi:10.1787/20745788

43. Institute for Laboratory Animal Research (ILAR). Guide for the Care and Use of Laboratory Animals. Washington, D.C.: National Academy Press; 1996.

44. Pingili R, Vemulapalli S, Mullapudi SS, Kondru S, Kilaru NB. Antidiabetic activity of methanolic leaf extract and different fractions of Zephyranthes candida in streptozotocin-induced diabetic rats. Iran J Pharmacol Ther. 2017;14(2):28-34. 
45. OECD guidelines for the testing of chemicals, section 4: health effects. Test No. 425: acute oral toxicity: up-and-down procedure. Paris: OECD Publishing; 2008. doi:10.1787/9789264071049-en.

46. Tesfaye A, Makonnen E, Gedamu S. Hypoglycemic and antihyperglycemic activity of aqueous extract of Justicia Schimperiana leaves in normal and streptozotocin-induced diabetic mice. Int J Pharm Sci Res. 2016;7(02):110-113.

47. Tamiru W, Engidawork E, Asres K. Evaluation of the effects of $80 \%$ methanolic leaf extract of Caylusea abyssinica (fresen.) Fisch. \& Mey. on glucose handling in normal, glucose loaded and diabetic rodents. BMC Complement Altern Med. 2012;12(1):1. doi:10.1186/1472-6882-12-151

48. Yanyan Z, Fu F, Ting C, Zhongwen L, Qingwu WS. Antidiabetic and antihyperlipidemic activities of Forsythia suspensa (Thunb.) Vahl (fruit) in streptozotocin-induced diabetic mice. J Ethnopharmacol. 2016;192:256-263. doi:10.1016/j.jep.2016.07.002

49. Sreejesh P, Thampi BH, Sreekumaran E. Hypoglycaemic effect of glibenclamide: a critical study on the basis of creatinine and lipid peroxidation status of streptozotocin-induced diabetic rat. Indian J Pharm Sci. 2017;79(5):768-777.

50. Hasan M, Mohieldein A. In vivo evaluation of anti diabetic, hypolipidemic, antioxidative activities of Saudi date seed extract on streptozotocin induced diabetic rats. J Clin Diagn Res. 2016;10(3):FF06. doi:10.7860/JCDR/2016/16879.7419

51. Belayneh YM, Birhanu Z, Birru EM, Getenet G. Evaluation of in vivo antidiabetic, antidyslipidemic, and in vitro antioxidant activities of hydromethanolic root extract of Datura stramonium L. (Solanaceae). J Exp Pharmacol. 2019;11:29. doi:10.2147/JEP.S192264

52. Cherie Melaku B, Amare GG. Evaluation of antidiabetic and antioxidant potential of hydromethanolic seed extract of Datura stramonium Linn (Solanaceae). J Exp Pharmacol. 2020;12:181-189. doi:10.2147/JEP.S258522

53. Baquer NZ, Kumar P, Taha A, Kale R, Cowsik S, McLean P. Metabolic and molecular action of Trigonella foenum-graecum (fenugreek) and trace metals in experimental diabetic tissues. J Biosci. 2011;36(2):383-396. doi:10.1007/s12038-011-9042-0

54. King AJ. The use of animal models in diabetes research. Br J Pharmacol. 2012;166(3):877-894. doi:10.1111/j.1476-5381.2012.01911.x

55. Hammeso WW, Emiru YK, Ayalew Getahun K, Kahaliw W. Antidiabetic and antihyperlipidemic activities of the leaf latex extract of Aloe megalacantha Baker (Aloaceae) in streptozotocin-induced diabetic model. Evid Based Complement Alternat Med. 2019;2019:8263786.

56. Toma A, Makonnen E, Mekonnen Y, Debella A, Adisakwattana S. Antidiabetic activities of aqueous ethanol and n-butanol fraction of Moringa stenopetala leaves in streptozotocin-induced diabetic rats. BMC Complement Altern Med. 2015;15(1):242. doi:10.1186/s12906-015-0779-0

57. Tas S, Tas B, Bassalat N, Jaradat N. In-vivo, hypoglycemic, hypolipidemic and oxidative stress inhibitory activities of Myrtus communis L. fruits hydroalcoholic extract in normoglycemic and streptozotocin-induced diabetic rats. Biomed Res. 2018;29(13). doi:10.4066/biomedicalresearch.2918-708

58. Gebremeskel L, Tuem KB, Teklu T. Evaluation of Antidiabetic Effect of ethanolic leaves extract of Becium grandiflorum Lam. (Lamiaceae) in streptozotocin-induced diabetic mice. Diabetes Metab Syndr. 2020;13:1481. doi:10.2147/DMSO.S246996

59. Hussein A. Evaluation of in vivo wound healing activity of $80 \%$ methanol crude extracts of the bulbs of Crinum abyssinicum in Mice (unpublished). Addis Ababa: Department of Pharmacology and Clinical Pharmacy; 2019.

60. Ramkumar KM, Vanitha P, Uma C, Suganya N, Bhakkiyalakshmi E, Sujatha J. Antidiabetic activity of alcoholic stem extract of Gymnema montanum in streptozotocin-induced diabetic rats. Food Chem Toxicol. 2011;49(12):3390-3394. doi:10.1016/j.fct.2011.09.027

61. Jangir RN, Jain GC. Evaluation of antidiabetic activity of hydroalcoholic extract of Cassia fistula Linn. pod in streptozotocin-induced diabetic rats. Pharmacogn J. 2017;9(5):599-606. doi:10.5530/pj.2017.5.95

62. Azzi A-S, Cosentino C, Kibanda J, Féry F, Cnop M. OGTT is recommended for glucose homeostasis assessments in Friedreich ataxia. Ann Clin Transl Neurol. 2019;6(1):161-166. doi:10.1002/acn3.686

63. Gebreyohannis T, Shibeshi W, Asres K. Effects of solvent fractions of Caylusea abyssinica (Fresen.) Fisch. and Mey. on blood glucose levels of normoglycemic, glucose loaded and streptozotocin-induced diabetic rodents. J Nat Remedies. 2013;14(1):67-75.

64. Al-Ishaq RK, Abotaleb M, Kubatka P, Kajo K, Büsselberg D. Flavonoids and their anti-diabetic effects: cellular mechanisms and effects to improve blood sugar levels. Biomolecules. 2019;9(9):430. doi:10.3390/biom9090430

65. Sun L, Warren FJ, Gidley MJ. Natural products for glycaemic control: polyphenols as inhibitors of alpha-amylase. Trends Food Sci Technol. 2019;91:262-273. doi:10.1016/j.tifs.2019.07.009

66. Kifle ZD, Yesuf JS, Atnafie SA. Evaluation of in vitro and in vivo anti-diabetic, anti-hyperlipidemic and anti-oxidant activity of flower crude extract and solvent fractions of Hagenia Abyssinica (Rosaceae). J Exp Pharmacol. 2020;12:151-167. doi:10.2147/JEP.S249964

67. Tomai F, Crea F, Gaspardone A, et al. Ischemic preconditioning during coronary angioplasty is prevented by glibenclamide, a selective ATP-sensitive K+ channel blocker. Circulation. 1994;90(2):700-705. doi:10.1161/01.CIR.90.2.700

68. Nugent DA, Smith DM, Jones HB. A review of islet of Langerhans degeneration in rodent models of type 2 diabetes. Toxicol Pathol. $2008 ; 36$ (4):529-551. doi:10.1177/0192623308318209

69. Jayaprasad B, Sharavanan P, Sivaraj R. Antidiabetic effect of Chloroxylon swietenia bark extracts on streptozotocin induced diabetic rats. Beni-Suef Univ J Basic Appl Sci. 2016;5(1):61-69. doi:10.1016/j.bjbas.2016.01.004

70. Wei X, Wen Y, Zhou Q, et al. Hyperlipidemia and mortality associated with diabetes mellitus co-existence in Chinese peritoneal dialysis patients. Lipids Health Dis. 2020;19(1):234. doi:10.1186/s12944-020-01405-5

71. Elangovan A, Subramanian A, Durairaj S, et al. Antidiabetic and hypolipidemic efficacy of skin and seed extracts of Momordica cymbalaria on alloxan induced diabetic model in rats. J Ethnopharmacol. 2019;241:111989. doi:10.1016/j.jep.2019.111989

72. Goutam N, Kapoor R. Evaluation of antidiabetic and antihyperlipidemic effect of ethanolic leaves extract of Centratherum anthelminticum (L) Kuntze against STZ induced diabetic rats. J Drug Deliv Ther. 2020;10(2s):140-148. doi:10.22270/jddt.v10i2-s.4014

Journal of Experimental Pharmacology

Dovepress

Publish your work in this journal

The Journal of Experimental Pharmacology is an international, peer-reviewed, open access journal publishing original research, reports, reviews and commentaries on all areas of laboratory and experimental pharmacology. The manuscript management system is completely online and includes a very quick and fair peer-review system. Visit http://www.dovepress.com/testimonials.php to read real quotes from published authors.

Submit your manuscript here: https://www.dovepress.com/journal-of-experimental-pharmacology-journal

Journal of Experimental Pharmacology 2022:14

$f$ in $\rightarrow$ DovePress 